\title{
Energy and Environmental Aptitude (EEA) to Assess Solar Energy Exploitation in Cities
}

\author{
Gracie la Me lis a Viegas*, Gustavo Alberto San Juan
}

IIPAC (Built Environment Policy Research Institute). FAU (School of Architecture and Planning). UNLP (National University of La Plata). La Plata. Street $47 \mathrm{~N}^{\circ} 162$, DC 478. (1900), Argentina

\begin{abstract}
In Argentina, the number of residential buildings (ho mes) has grown 20\% in the last decade (2000-2010), thus increasing the level of non-renewable energy consumption of the residential area per inhabitant $(0.25 \mathrm{TOE}$ per capita per year in 2000, 0.3 TOE per capita per year in 2010) and lowering the construction quality. This situation has a significant impact on the GHG emissions to the environment. W ithin this context, this paper aims to assess the energy and environmental aptitude (EEA) of residential building groups in characteristic urban areas (urban mosaics), to estimate the potentiality of solar energy and energy efficiency exploitation. To begin with, the following urban area variables were calculated from aerial and satellite image classification techniques: i. Horizontal heat dissipation area; ii. Construction system of horizontal heat dissipation area - Roofs; iii. Vertical heat dissipation perimeter - Walls; iv. Built-up area height. Then, obtained results were exposed on two characteristic urban areas, differing in the compactness of its fabric, what allowed to evaluate that the urban area of greater compactness presented lower energy loss and similar EEA in relation to the urban area of lower compactness. This conclusion contributes to the discussion about the diffuse city and the compact city, since it reinforces the need to develop urban conglomerates with greater building compactness.
\end{abstract}

Keywo rds Energy and Environ mental Impact on Urban Areas, Urban Mosaics, Image Classification

\section{Introduction}

Urban planning allows city council authorities to have a mid- and long-term vision since it influences the future development of cities. This is why it plays a key role in the creation of communities that lead this develop ment to a more sustainable position between culture and nature.

There are two key factors to consider for a sustainable urban planning: occupation and socio-territorial models and patterns, and urban energy services production (demand-supply), such as natural gas or electrical energy. They determine the economic and productive activities as well as mobility, production and building construction; consequently, they influence the volu me of generated GHG emissions.

As regards the urban occupation model, it is remarkable the role played by buildings as urban environ ment and not as individual technical objects. The reduction in energy consumption and current emissions will not be achieved unless the built-up area is considered as a whole; in particular, the existing built-up area has to be taken into account. However, the biggest efforts in the last years have been centered in the design of new efficient buildings while less attention has

* Corresponding author:

gachiviegas@yahoo.com.ar (Graciel a Melisa Viegas)

Published online at http://journal.sapub.org/re

Copyright (C) 2012 Scientific \& Academic Publishing. All Rights Reserved been paid to the improvement of existing buildings and the infrastructure supporting them[1].

As far as energy services are concerned, it is understood that the incorporation of solar origin renewable services (electric or thermal generation) implies a reduction in GHG emissions. In this respect, Rueda[2] stands out that it is fundamental to incorporate and sustain urban organization with renewable energies as basic resource to reduce impact over the atmosphere, understanding the city as an open system where energy planning is necessary[3]; he proposes to use them as an essential and applicable strategy to promote sustainable development[4].

In Argentina, the growth of the residential build ings is still sustained (20\% in the $2000-2010$ decade according to data from the INDEC - National Institute of Statistics and Censuses, according to its acronym in Spanish)[5]. But this growth has been developed without incorporating an improvement in the construction quality or other energy sources that allow energy savings given the current levels of consumption or interior comfort improvements. This is shown in the national energy balance[6] that presents - in the national energy matrix, non-renewable energy consumption levels in the residential sector (main ly natural gas, electrical energy and bottled gas) in the year 2000 of 0.25 TOE per capita per year, with an increase of $0.3 \mathrm{TOE}$ per cap ita per year in 2010. It is then essential to improve this situation to avoid a greater impact on the environment and the depletion of the resources available. Now, how can we know the po- 
tentiality to exploit solar energy and improve energy efficiency in build ings?

Given this situation, it is necessary to develop tools, such as energy models, for the decision-makers to help in the following aspects:(i) to manage quality imp rovements in the built-up environment; (ii) to determine where to invest resources to achieve greater benefits[7]; (iii) to accompany improvement processes of building energy and thermal quality with the modification of the current leg islation. At present, most tools tend to consider the building as a sole entity and not from the urban scale perspective[8].

Therefore, to further these aspects, it is necessary to study the relation between buildings and their energy and environmental aptitude (EEA) to use energy in a more efficient way or replace it with alternative sources. It will also be useful for the application in building massive recycling strategies, which have proved to be very successful in different countries, getting at present up to $80 \%$ of energy savings with different technical-economic viability[10][1]. At methodological level, several research analyzing the urban block (urban fabric minimal unit that circumscribes buildings and that is limited by streets, also called four-sided square in chessboard layout) and the building envelope back up this development[11][12][13][14]. The EEA is analyzed with a methodology applied to urban mosaics previously developed[15].

\subsection{Urban Mosaics}

Urban mosaics (UM) are characteristic areas which are representative of bigger ones. They have been studied by different disciplines, such as art, landscape ecology and sociology[16][17][18][19]; in this case, they strictly refer to the urban space, what poses the need to go into the morphological aspects for their classification using different variables and indicators (Figure 1). UMs main components are building units associated to recognizable building typologies, located in parcels. Many of them will make up an urban block and they, in turn, associate among themselves through the public spaces of the streets, pavements and voids, at a particular distance. The disposition, characterization, shape and occupation of their components over the territory shape one kind of urban mosaic which is defined as a characteristic pattern[20].

Its analysis and processing can be done in manual, semi-automatic or auto matic way.

In the manual procedure, there is qualified observation of aerial or satellite images and the survey of the areas is done in situ; then, the data collected is drawn in two and three dimensions (with CAD programs) to calculate size and shape of build ings. Finally, through direct observation, surveyed building units are assimilated to the study area historical records about recognizable building typologies. This procedure is really time-consuming.

$\{0>$ Ante esta situación, se observaron los avances desarrollados por la ecología del paisaje y por la teledetección. $<\} 100\{>$ Given this situation, the advances made by landscape ecology and remote sensing were considered. $<0\} \quad\{0>$ La primera, incorporó el análisis de la fotografía satelital y aérea, y el uso de los sistemas de información geográfica (SIG) que complementan bases gráficas y numéricas de distintas áreas extensas[21]. $<\} 94\{>$ The former incorporates the analysis of satellite and aerial photography, and the use of geographic information systems (GIS) that complement graphic and numerical databases of extended areas[21]. $<0\} \quad\{0>$ Por su parte, la teledetección en ámbitos urbanos sobre imágenes, permite numerosas aplicaciones que van desde estimación de la población, la cuantificación de cambios, la estimación de la densidad de edificación, la detección de asentamientos urbanos y rurales, en forma continuada y actualizada, lo que le confiere una indudable utilidad de cara a la gestión y planificación del desarrollo urbanístico[22]. $<\} 92\{>$ The latter, in urban environments, has a lot of applications that range from population estimation to change quantification, building density estimation, and urban and rural detection in a continuous and updated way. This is why remote sensing is so useful for urban development planning and management. $<0\}$
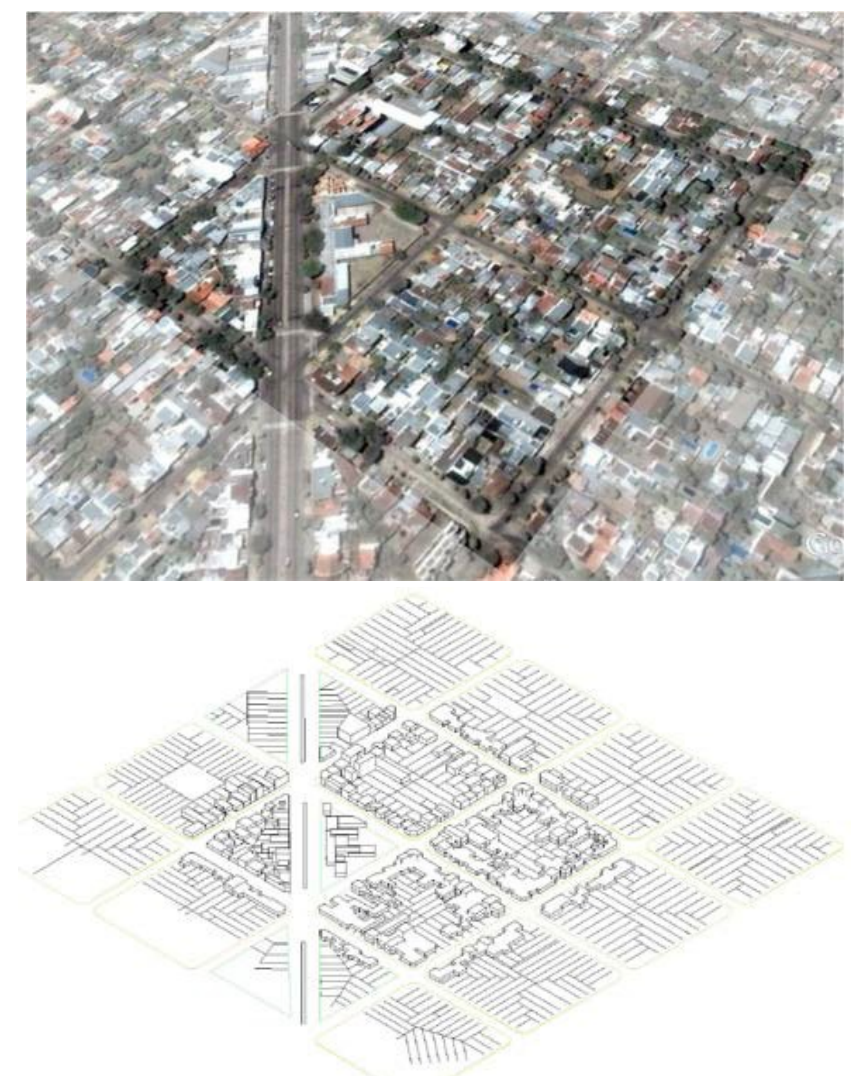

Figure 1. Urban Mosaic: satellite image and simplified volumetry of the area

According to these antecedents, it was observed that, through the combination of resources and techniques, it is possible to compare and devise indexes for studying UMs in an automatic way, simplify ing the in situ survey work. 
Consequently, this paper aims to expose a methodology that complements the concept of UM previously developed. The proposed methodology determines the EEA inferred and calculated from the detection of the following variables: horizontal heat dissipation area, construction system of the horizontal heat dissipation area, vertical heat dissipation perimeter and built-up area height on satellite and aerial urban images. Such methodology is developed and applied on two characteristic sectors to evaluate their EEA.

\section{Methodology}

Buildings are modelled in their exterior envelope by applying segmentation techniques on urban images (details are omitted because volumetry influence exceeds the importance of details)[11]. In remote sensing, the image segmentation process is defined as the search for homogeneous regions in an image and the classification of these regions[19]. It allows to extract different types of characteristics from the outstanding objects. For this methodology, we are specifically interested in the following characteristics -geometry (shape and size), localization (height, width, area, perimeter, shape factor, etc.), intensity and brightness of the reg ion and neighbourhood. The different techniques are applied through the functions developed in the Image Processing Toolbox 7 , MATLAB software type. For the analysis, digitalized analogical aerial images in scale 1:20,000[22] were used, as well as free access satellite images [23].

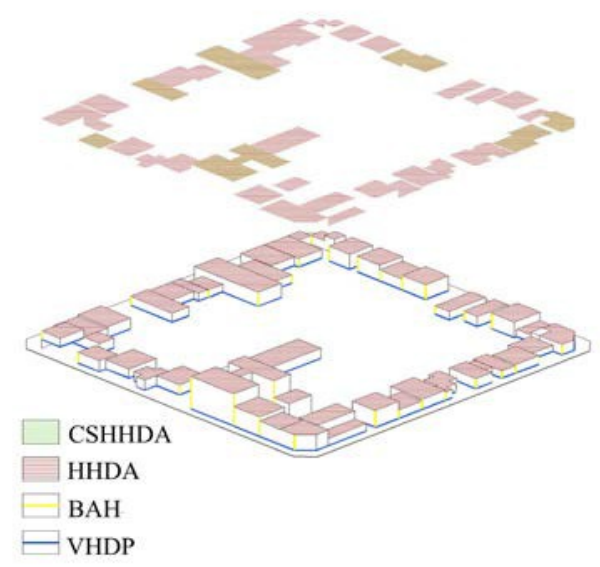

Figure 2. Volumetry of an urban block or square (urban fabric minimal unit circumscribing the buildings) with the delimit at ion of the analysis variables: horizontal heat dissipation area, construction system of the horizontal heat dissipation area, vertical heat dissipation perimeter, built-up area height

The following variables used to calculate the EEA of an urban sector were analized, and they are summarized in Figure 2:

i. Delimitation and measuring of the built-up area and the empty area of the urban mosaic to get the horizontal heat dis sipation area (HHDA).

ii. Ho rizontal heat dissipation area classification to get the constructive system of the horizontal heat dissipation areaRoofs (tiles, reinforced concrete slab, metal sheet)
(CSHHDA).

iii. Delimitation and measuring of the built-up area outline to get the vertical heat dis sipation perimeter (VDP).

iv. Delimitation of buildings shadows to know the built-up area height $(\mathrm{BAH})$.

The information collected is represented as vector file (dwg, dxf, etc.), which is used in computer-aided drawing programs (CAD) or geographic information systems (GIS). In this way, a database with the urban-morphological characteristics of a city sector or UM is achieved.

From the operation of the exposed variables, the EEA of an urban sector can be calculated, and different types of urban fabric compositions can be evaluated or compared according to the best energy performance or energy potential. For this purpose, ad hoc models are used in compliance with existing standards, regulations and estimations.

Up to now, seven EEA indicators were used, the first three related to energy loss and the remaining four, to solar gain potentials:

- Buildable surface explo itation (BSE).

- Exposed envelope of built-up volume (EEBV).

- Energy loss through roofs per built $\mathrm{m}^{2}$ in winter period (ELR).

- Solar access in facades (SAF).

- Solar access in roofs (SAR).

- Solar gain through windows per built $\mathrm{m}^{2}$ in winter period (SGW).

- Use of roof surface for solar water heating (URSWH).

\subsection{Variable Calculation}

\subsubsection{Horizontal Heat Dissipation Area (HHDA)}

This variable is analyzed in four stages: i. thresholding segmentation on greyscale images; ii. morphological gradients on the aforementioned resulting images; iii. labelling of each region on the previous image; iv. HHDA quantification. For stage i., the thresholding segmentation technique was applied (separating the objects of interest from the rest on the basis of pixel value) on digitalized analogical aerial images in greyscale in scale $1: 20,000$ [24]. The image was segmented according to the histogram, given that the various objects of the image present different grey levels. From the histogram, a threshold was chosen since it is the point whose intensity separates, in this case, the pixels belonging to the buildings from the background (vegetation and land), with a threshold value 200. In the resulting image, the regions detected are very irregular, they are open o isolated little detections that can be deemed wrong since they do not belong to any building.

For stage ii., the starting point is the resulting image where the regions are closed and the object structure is simplified by the application of morphological gradients (dilation and erosion). For this, an image sweep is performed with a 9x9 square structuring element in order to quantify the way it is confined, getting as a result a new image with the simplification of the objects making up the urban area in regular shapes. In this way, detections are more defined, even though 
small objects persist that have to be eliminated since they do not correspond to buildings.

For stage iii., a labelling of each region was performed on the previous image, and those regions with a size lower than $20 \%$ of average size were eliminated. The result is a very well-defined image, with regular objects, very close to reality.

For stage iv., binary objects are surveyed (buildings-background) defining the HDA (white colour areas). The quantity of pixels making it up is quantified and it is turned into a metric system scale.

Figure 3 shows the images resulting from i, ii, iii and iv.
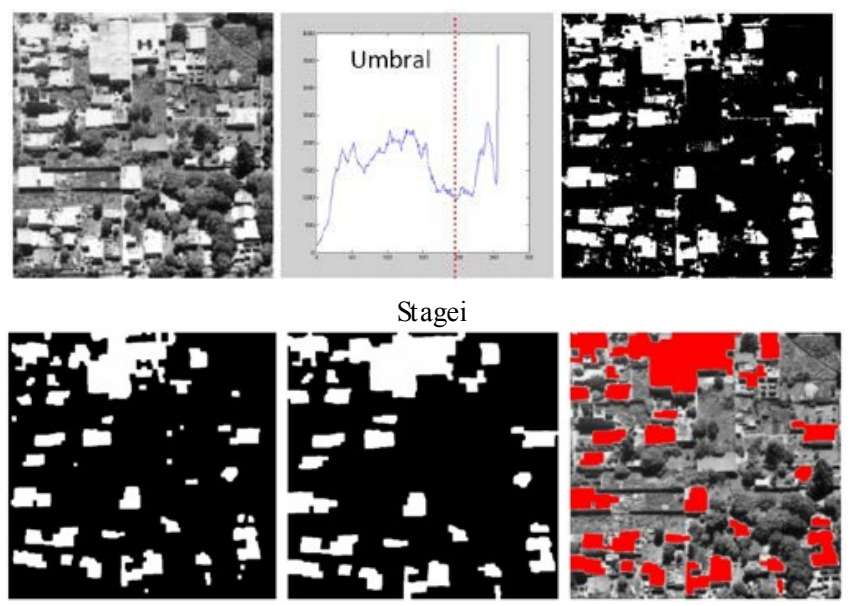

Stage ii

Stage iii

Stageiv

Figure 3. From the original aerial image of an urban block, the succession of results of stage i (thresholding segment ation); ii (morphological gradients on previous result ing images), iii (labelling of each region of the previous image) and iv (result ing image to quantify the HHDA)

\subsubsection{Constructive System of the Horizontal Heat Dis-} sipation Area - Roofs (CSHHDA)
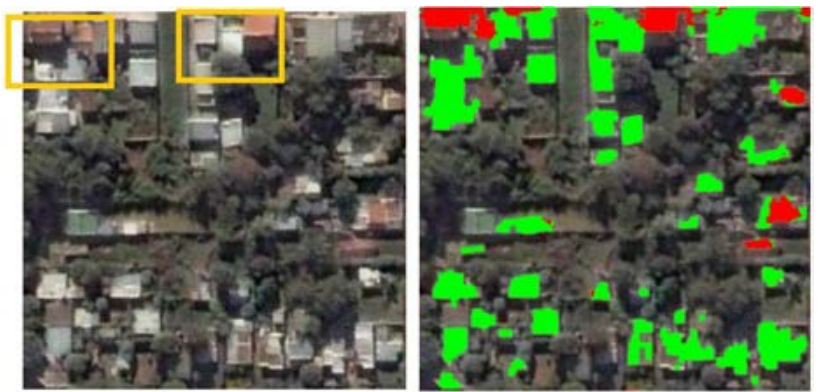

Figure 4. Thresholding on colour satellite image to determinethe constructive system of the horizontal area. Segmentation on the satellite image incorporating only one threshold (separat ing red colour of roofs from the rest)

In this case, the thresholding segmentation technique is also used, with the only difference that colour satellite images are used here to know the textures of the objects' horizontal area. Thresholds are chosen in the points dividing the dif- ferent colours of each roof constructive system. Broadly, there are three usual kinds of constructive systems: concrete slab (white colour, brighter), metal sheet (grey) and tiles (mostly red). To these three classes there correspond two thresholds, one to divide the whites in the image from the rest, and the other to divide the red parts from the rest.

In Figure 4, the original satellite image is observed, together with the thresholding segmentation on the satellite image separating colour red from the rest. A threshold that classified build ings with tile roofs (red) was incorporated.

\subsubsection{Vertical Dis sipation Perimeter (VDP)}

The borders of an object in a greyscale image can be defined as the transitions between two regions with significantly different levels of grey. To delimit borders and measure buildings' perimeter, the technique used is border detection from images resulting fro $m$ the HHDA.

Border detection was previously performed on the two types of HHDA resulting images used, greyscale aerial and colour satellite. It was observed that the results from the aerial image present greater regularity in the borders than in the satellite image; so the former was used. Results are observed in Figure 5.
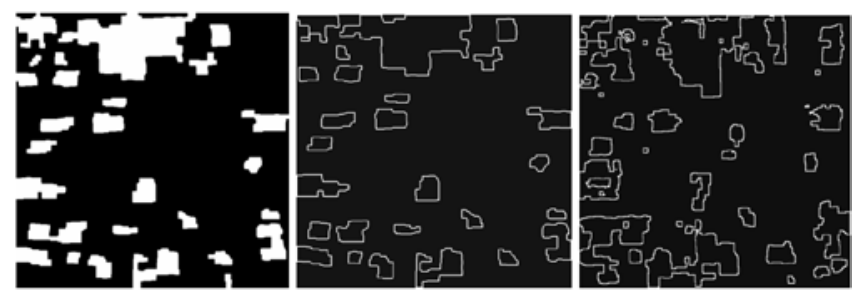

Figure 5. From the result of HHDA, borders are detected to quantify the VPD. First image: result of Figure 3, stage iii. Second image: VDP of an aerial image. Third image: VDP of a satellite image for the very same urban block

\subsubsection{Built-up Area Height (BAH)}

The information about the height was obtained from the shadows shown by the shadows of the buildings. In this case, the thresholding segmentation technique and the morphological gradients techniques were used on aerial images for shadow detection. An initial thresholding with a threshold value 67 made it possible to get a binary image with every type of shadow conveyed (from buildings, vegetation, common walls, or any other badly classified dark object).

The next step was to eliminate those shadows of no use for this analysis by means of morphological operations. It was then necessary to have the following additional information: the binary images resulting from HHDA delimitation, and the sun position that could be determined by the operator. Then all those shadows conveyed by built-up areas were selected. For the case of this particular image (figure 6, third image), they were all those shadows (blue colour) which were below the built-up area (red colour). All the zones that did not correspond to this pattern were eliminated, that is vertical shadows corresponding to fences, common walls and the like.

Then, the open irregular shadows were closed with a $5 \times 5$ rectangular structuring element with a dilation operation. Last, an image sweep is performed to eliminate shadows that did not correspond to any construction detected.

In Figure 6, a succession of images combining the HHDA with its respective shadow conveyed is presented (useless 
shadows were eliminated).
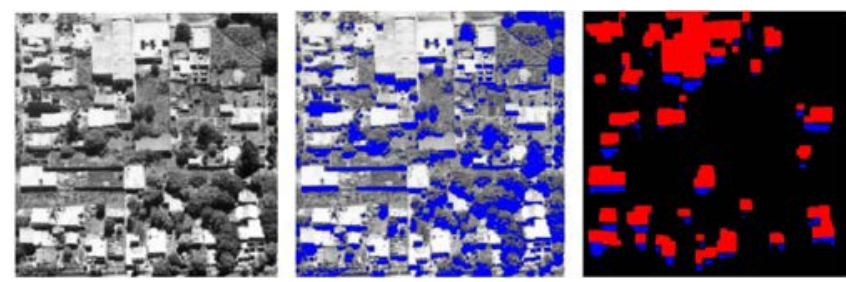

Figure 6. Procedure to determine construction height, from left to right: original aerial image; buildings and veget at ion shadows together; result ing image with the buildings (red colour) and the shadows conveyed by them (blue colour)

The construction height is deduced relating the solar height angle and the length of the shadows conveyed by the buildings through trigonometric functions.

\subsection{EEA Indicator Calculation}

Energy loss indicators are calculated in the following way:

- Buildable surface exploitation (BSE): it indicates the proportion of land occupied with construction.

BSE $=$ built-up area $\left(\mathrm{m}^{2}\right) /$ buildable area $\left(\mathrm{m}^{2}\right)$

- Exposed envelope of built-up volume (EEBV): it indicates that to greater value, greater thermal loss due to the fact that there is mo re exposed envelope to the exterior in relation to the built-up volume.

EEBV $=$ exposed envelope $\left(\mathrm{m}^{2}\right) /$ built-up volume $\left(\mathrm{m}^{3}\right)$

- Energy loss through roofs per built $\mathrm{m}^{2}$ in winter period (ELR): product of HHDA multiplied by an average thermal transmittance coefficient $\left(\mathrm{U}\right.$ in $\left.\mathrm{W} / \mathrm{m}^{2}{ }^{\circ} \mathrm{C}\right)$ of the closings making up said surface detected in the CSHHDA.

$\operatorname{ELR}\left(\mathrm{kW} \mathrm{m} \mathrm{m}^{2}\right.$ winter $)=\operatorname{HHDA}\left(\mathrm{m}^{2}\right) * \mathrm{U}$ coefficient $\left(\mathrm{kW} / \mathrm{m}^{2}{ }^{\circ} \mathrm{C}\right) *$ heating degree day $\left.\left({ }^{\circ} \mathrm{C}\right)\right) /$ built-up area $\left(\mathrm{m}^{2}\right)$

Solar ga in indicators are calculated in the following way:

- Solar access in facades (SAF): it counts the sunny surfaces of northeast and northwest facades, and front and rear-front of the UM blocks, and it compares them with the total surface of facades of each UM.

SAF $=$ sunny facade $/$ total facade $* 100$

- Solar access in roofs (SAR): it counts the sunny roof surface and compares it to the total roof surface of each UM.

SAR $=$ sunny roof surface / total roof surface $* 100$

- Solar gain through windows per built $\mathrm{m}^{2}$ in winter period (SGW): Solar gains through windows surfaces percentage consider simple g lass windows.

SGW $\left(\mathrm{kW} \mathrm{m}{ }^{2}\right.$ in winter $)=$ energy gained through windows $(\mathrm{kWh})$ / built-up area $\left(\mathrm{m}^{2}\right)$

- Use of roof surface for solar water heating (\%) (URSW H): considering only $50 \%$ of the roofs available, it indicates in a relative way the surface used to cover the hot water demand by the inhabitants of the UM.

URSWH $=$ necessary surface $(\mathrm{m} 2)$ to produce SWH per inhabitant * total number of UM inhabitants / sunny roof surface available $(\mathrm{m} 2) * 100$

\section{Case Study}

The methodology was applied on two urban mosaics in La Plata, Buenos Aires, Argentina.

This city is located in the Northeast of Buenos Aires province, $60 \mathrm{~km}$ away from the City of Buenos Aires, $-34^{\circ}$ $55^{\prime}$ latitude (South) and $-57^{\circ} 17^{\prime}$ longitude (West). Its total surface is $821 \mathrm{~km}^{2}$. Its height above sea level ranges between 0 and 15 meters, and it is geomorphologically characterized by the plain (Pampeana plain); it has temperate-humid climate[24]. The city of La Plata was funded in 1882 as the capital of the province and built according to the layout of the urban engineer Pedro Benoit. It was materialized as a reflection of the hygienist urbanism of the end of the XIX century as regards street amplitude and wooded avenues, which ensured comfort, ventilation and cleanliness [25].

Two sectors of the urban area were selected. They are both similar regarding: land use (mainly residential), regular urban layout $(10 \mathrm{~m}$ frontage parcels) and orientation (NE-SW). The differences lay in the compactness of the urban fabric (the degree of compactness indicates the predominance of built-up volu mes over empty spaces), which is represented by the urban consolidation (see Figure 7). From this classification, it was calculated that average consolidation areas (20-40 homes per hectares) represent $17.30 \%$ (1332 hectares) of the urban area extension of La Plata with 154,091 inhabitants (116 inhabitants per hectare). Low consolidation areas (less than 20 homes per hectares) represent $80.49 \%$ of the total $(6,196$ hectares $)$, with a population of 377,107 inhabitants (65 inhabitants per hectare). High consolidation areas (more than 40 homes per hectare) representing around $2.2 \%$ of territorial extension are not considered. This first diagnosis shows the disperse fabric characteristic of most areas in the city.

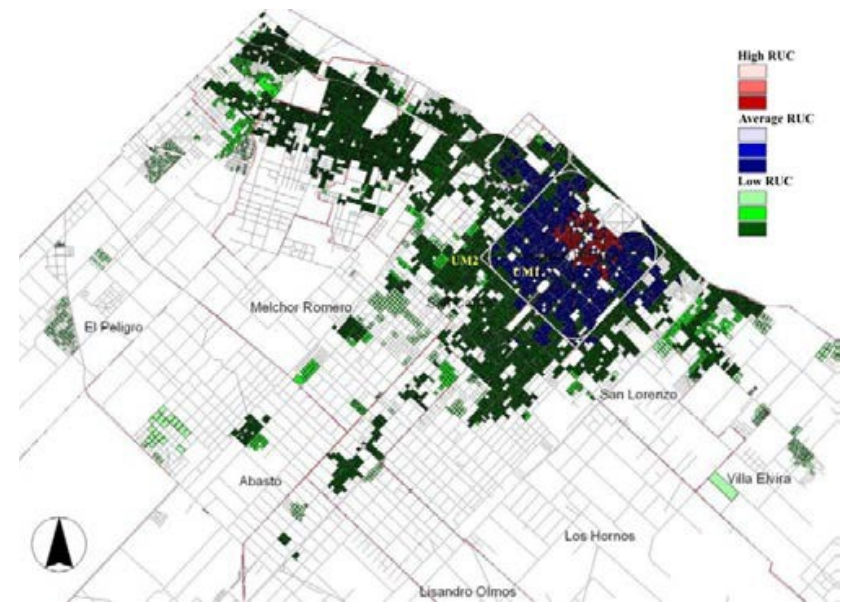

Figure 7. La Plata divided according to residential urban consolidation (RUC). It concentrat es the following variables: number of homes per hectare and the existence of basic infrastructure services, specifically nat ural gas. Delimitation in yellow of the urban areas to analize 
Table 1. Numerical results of the variables analized: HHDA, CSHHDA, VDP, BAH. The followingvariables are calculated from the initialvariables: volume, facade surface, northeast and northwest facades

\begin{tabular}{ccc}
\hline & UM1 Ave rage consolidation & UM2 Low consolidation \\
\hline${\text { HHAD }\left(\mathrm{m}^{2}\right)}$ & $23,947.0$ & $7,599.0$ \\
\hline CSHHDA: Sheet $\left(\mathrm{m}^{2}\right)$ & $7,184.1$ & $3,419.5$ \\
\hline CSHHDA: Slab & $5,627.5$ & $2,636.8$ \\
\hline CSHHDA: Tile & $3,592.0$ & 721.9 \\
\hline CSHHDA: Others ${ }^{(1)}$ & $7,543.3$ & 820.7 \\
\hline VDP $(\mathrm{m})$ & $5,662.0$ & $3,926.0$ \\
\hline BAH average $(\mathrm{m})$ & 5.27 & 4.13 \\
\hline Volume $\left(\mathrm{m}^{3}\right)^{(2)}$ & $119,337.0$ & $34,566.0$ \\
\hline Facade surface $(\mathrm{m})^{(3)}$ & $29,815.27$ & $16,232.88$ \\
\hline Northeast and northwest facades $(\mathrm{m})$ & $6,850.0$ & $3,300.0$ \\
\hline
\end{tabular}

(1) It refers to sheds and outbuildings, not considered in this study. (2) Volume is presented as the result of HHDA * BAH. (3) Calculated from BAH and VDP, or extracted from volumetry

Table 2. EEAIndicat ors Results

\begin{tabular}{|c|c|c|}
\hline $\begin{array}{c}\{0>\text { Aptitud Energético Ambiental }<\} 100\{>\text { Ene rgy and } \\
\text { En vironmental Aptitu de }<0\}\end{array}$ & $\begin{array}{c}\{0>\text { MU } 1<\} 100\{>\mathbf{U M 1}<0\} \\
\{0>\text { Baja cons. }<\} 100\{>\text { Average } \\
\text { consolidation }<0\}\end{array}$ & $\begin{aligned} \quad\{0>\text { MU2 } \\
\text { Altacons. }<\} 100\{>\text { UM2 } \\
\text { Low consolidation }<0\}\end{aligned}$ \\
\hline \multicolumn{3}{|l|}{$0>$ De PERDIDAS $<$} $100\{>$ LOSSES $<0\}$ \\
\hline $\begin{array}{c}\left\{0>\text { ASE- Aprovechamiento superficie edificable }{ }^{(1)}<\right\} 100\{>\text { BSE }- \\
\left.\text { Buildable Surface Exploit at ion }{ }^{(1)}<0\right\} \\
\{0>(\text { adim. }<\} 100\{>(\text { dimensionless })<0\}\end{array}$ & 0.42 & 0.13 \\
\hline $\begin{array}{c}\{0>\text { EEVE- Envolvente expuesta volumen edificado } \\
(\text { adim. })<\} 100\{>\text { EEBV }- \text { Exposed envelope built-up volume } \\
(\text { dimensionless })<0\}\end{array}$ & 0.45 & 0.69 \\
\hline $\begin{array}{c}\{0>\text { PET- Pérdida energía techos. }<\} 99\{>\text { ELC }- \text { Energy loss roofs }<0\} \\
\left\{0>(2)\left(\mathrm{kWh} / \mathrm{m}^{2} \text { invierno }\right)<\right\} 100\left\{>^{(2)}\left(\mathrm{kWh} / \mathrm{m}^{2} \text { winter }\right)<0\right\}\end{array}$ & 1.90 & 2.67 \\
\hline \multicolumn{3}{|l|}{$0>$ De GANANC IAS $<$} $100\{>$ GAINS $<0\}$ \\
\hline $\begin{array}{c}\{0>\text { ASF- Acceso solar fachadas }<\} 100\{>\text { SAF - Solar access } \\
\text { facades }<0\} \\
(3)(\%)\end{array}$ & 89.00 & 97.00 \\
\hline $\begin{array}{c}\left\{0>\text { AST- Acceso solar techos }{ }^{(4)}(\%)<\right\} 100\{>\text { SAR - Solar access } \\
\left.\operatorname{roofs}^{(4)}(\%)<0\right\}\end{array}$ & 85.00 & 97.00 \\
\hline $\begin{array}{c}\left\{0>\text { GSV- Ganancia solar- ventanas }{ }^{\left({ }^{5}\right)}\left(\mathrm{kWh} / \mathrm{m}^{2}\right.\right. \\
\text { invierno })<\} 99\left\{>\text { SGW - Solar gain windows }{ }^{(5)}\left(\mathrm{kWh} / \mathrm{m}^{2} \text { winter }\right)<0\right\}\end{array}$ & 4.73 & 7.63 \\
\hline $\begin{array}{c}\left\{0>\text { UT- ACS- Uso techos Agua caliente solar }{ }^{(6)}\right. \\
(\%)<\} 100\left\{>\text { URSWH }- \text { Use of roofs solar water heating }{ }^{(6)}(\%)<0\right\}\end{array}$ & 30.00 & 41.00 \\
\hline \multicolumn{3}{|c|}{$\begin{array}{l}\text { Buildable area: } 57,600 \mathrm{~m}^{2} \text { (UM1); } 60,766 \mathrm{~m}^{2} \text { (UM2). (2) Applied thermal transmittance coeffi cient }\left(\mathrm{U}: \mathrm{kW} / \mathrm{m}^{2}{ }^{\circ} \mathrm{C}\right): 0.00099 \mathrm{~kW} / \mathrm{m}^{2}{ }^{\circ} \mathrm{C}(\mathrm{sheet}) ; 0.00382 \mathrm{~kW} / \mathrm{m}^{2}{ }^{\circ} \mathrm{C} \\
\text { (rein forced con crete slab); } 0.0008 \mathrm{~kW} / \mathrm{m}^{2}{ }^{\circ} \mathrm{C} \text { (tile). La Plata heating degree day (based on } 20^{\circ} \mathrm{C} \text { Comfort Level): } 1,448 \text {. (3) With volumetry obtained, potential sun } \\
\text { collecting facades (NE and NW oriented) are calculated together with the sunlight they get on the critical winter day (solstice). This day is used as the basis to } \\
\text { calculate the whole winter period (June, July, August). (4) With the volumetry, the sunlit horizontal surface for the critical winter day is calculated (solstice). Sunlit } \\
\text { horizontal area: } 20,354.95 \mathrm{~m}^{2} \text { (UM1); } 7,219.05 \mathrm{~m}^{2} \text { (UM2). (5) The energy received through windows is } 2.12 \mathrm{~kW} / \mathrm{m}^{2} \text { average per day for the critical winter day. In the } \\
\text { study region, } 65 \% \text { of winter days ( } 60 \text { days) have this solar gain, the rest is very low. } 15 \% \text { of NE and NW facad es are supposed to have windows. (6) It is considered } \\
\text { that } 7 \mathrm{~m} \text { ' of the horizontal surface for SWH are necessary per inhabitant in the study region. Inhabitants: } 432 \text { (UM1); } 213 \text { (UM2) }\end{array}$} \\
\hline
\end{tabular}

\subsection{Energy and Environmental Aptitude Calculation}

In Table 1, the result of the variables calculated and of those resulting from the quantification of the urban sector volumetry (HHAD, CSHHDA, VDP, volu me, facade surface) is observed. In Figure 8, volu metry is observed.

From results in Table 1, Table 2 shows the calculus of EEA indicators for both areas.

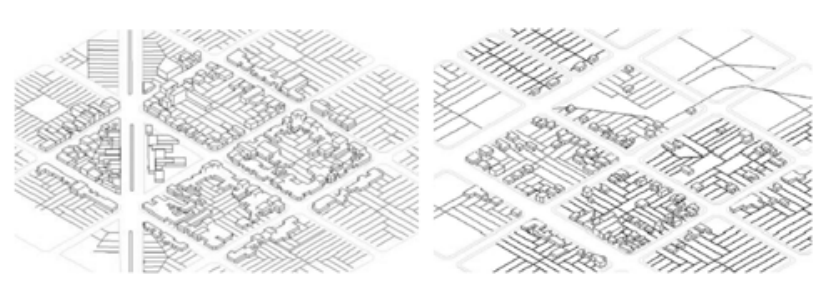

Figure 8. Urban mosaics volumetry (UM1 and UM2) developed from the analysis variables 


\section{Discussion}

From the EEA indicators applied to the two sectors, we can observe:

- The average consolidation mosaic (UM1) has a higher BSE indicator (0.41) than the low consolidation mosaic (UM2) (0.12). This means that the buildable surface is used more efficiently in the former.

- The average consolidation mosaic has a lower EEBV indicator $(0.45)$ than the low consolidation one (0.69), which translates into fewer losses per envelope.

- The average consolidation mosaic (UM1) has fewer losses through roofs $\left(1.90 \mathrm{~kW} \mathrm{~m} \mathrm{~m}^{2}\right.$ winter $)$ in comparis on with the other mosaic (UM2) $\left(2.67 \mathrm{~kW} \mathrm{~m}^{2}\right.$ winter). This shows that the former has the best thermal quality of all the roof constructive systems.

- Both mosaics present similar values in the SAF and SAR indicators (between $85 \%$ and $97 \%$ ), which means that the solar obstruction degree due to self-portrayed shadow is not significant in either of them.

- The average consolidation mosaic (UM2) has a lower SGW indicator $\left(4.73 \mathrm{~kW} / \mathrm{m}^{2}\right.$ winter) in comparis on with the low consolidation mosaic (UM1) $\left(7.63 \mathrm{~kW} / \mathrm{m}^{2}\right.$ winter). This evidences that the surfaces of potential sun collecting facades are proportionally bigger in the low consolidation mosaic.

- Both mosaics present low URSWH indicators $(30 \%$ and $40 \%$ in UM 1 and UM2, respectively). This shows that roofs, as potential surfaces to incorporate solar water heaters, give the possibility to be also used for other applications, such as photovoltaic power generation.

To sum up and to relate thermal loss indicators with thermal gain ones, we can conclude:

- In comparison with the low consolidation mosaic (UM2), urban areas represented by the average consolidation mosaic (UM 1) present better exploitation of the buildable area, s maller exposed envelope area, fewer energy losses through roofs, similar percentages of solar blocking in facades and roofs, significantly lower solar gain through windows, and larger surface of available roofs to incorporate power generation solar systems.

- Consequently, these urban areas represented by the UM2 have a better EEA for the exploitation of renewable energies.

- Considering population and territorial extension of the areas studied, it is possible to conclude that $17 \%$ of the total territory of La Plata (home to $27 \%$ of the population) present better EEA indicators. Likewise, approximately $80 \%$ of the territorial extension has a lower EEA, even though there is better potential for energy gain exploitation due to the lower building compactness.

\section{Conclusions}

\subsection{Instrumentation}

The results exposed show that semiautomatic object interpretation procedures are suitable for UM's requirements.

These procedures have simplified urban survey, minimized field study and reduced operator's time. They significantly contribute to the improvement in the efficiency of the interpretation of urban areas, combining measuring speed with the operator's interpretation ability.

The application of this UM processing technique allowed to know the characteristics of both UMs and, with such information, perform the spatial modelling and the shape and quantitative synthesis of its variables to calculate EEA indicators.

As regards the images used for this work in particular, some considerations about the pros and cons of aerial and satellite photography. The advantage of aerial photography is its good spatial resolution and, consequently, good border definition. It also allows to know the date and time of the photo taking and thus estimate sun position. Within its disadvantages, we may say aerial photography has fallen into disuse due to its high costs - so the information surveyed becomes easily out of date, and the grey scale does not allow to positively spot the constructive system of the horizontal surfaces (roofs).

On the other hand, satellite photography does allow to discriminate the constructive system of horizontal surfaces thanks to the existence of different color bands (RGB). However, as the images are made up of several takings (different dates and times), sun position cannot be determined. Moreover, free-access satellite images do not have appropriate spatial resolution and border definition, what leads to imprecise detections.

\subsection{Energy Planning and Manage ment}

By means of this methodology, areas can be evaluated to improve their energy and environmental conditions and to know those residential gatherings more appropriate to promote more sustainable occupation models.

Likewise, it allows to propose measures to improve energy management in the city according to the potentialities of each sector.

\subsection{Energy and Environmental Aptitude (EEA)}

As regards indicators devising, we can conclude that it has allowed us to establish the differences between both sectors and to elaborate conclusions for their imp rovement.

Thanks to them, more sectors can be studied with the same methodology, broadening the knowledge of such a vast and comple $\mathrm{x}$ area as the residential sector of the city is.

Moreover, more specific indicators can be incorporated: energy loss through all the elements of the envelope (windows, floors, walls, and so on); gains from other energy generation sources, such as thermal storage walls, solar hot air collector, or photovoltaic systems, among others. They will be studied for future application.

\section{ACKNOWLEDGEMENTS}


This research has been partly financed by the CONICET. Special thanks to Verónica Artola from the LIDI - UNLP[IT Reseach Institute - National University of La Plata, according to their acronyms in Spanish], at the first stage of subject approach. Special thanks to Agustina Go mez for her contribution in the translation of the text.

\section{REFERENCES}

[1] G. Verbeeck, H. Hens, "Energy Savings in Retrofitted Dwellings: economically viable?", Elsevier, Energy and Buildings, v. 37, n. 5, p. 747-754, 2005.

[2] Online available: http://habitat.aq.upm.es/cs/p2/a009.html

[3] Virgilio Vettini. Elementos de ecología urbana. Editorial Trotta, Madrid, España, 1998.

[4] A. K. Athienitis, M. Santamouris, Thermal Analysis and Design of Passive Solar Buildings, The Cromwell Press, UK, 2002.

[5] Online available: http://www.censo2010.indec.gov.ar/resulta dosdefinitivos_tot alpais.asp

[6] Online available: http://energia3.mecon.gov.ar/contenidos/v erpagina.php ?idpa gina $=3366$.

[7] P. Jones, J. Patterson, S. Lannon, "Modelling the Built Environment at an Urban Scale: energy and health impacts in relation to housing", Elsevier, Landscape and Urban Planning, v. 83, n. 1, p. 39-49, 2007.

[8] C. Ratti, N. Baker, K. Steemers, "Energy Consumption and Urban Texture", Elsevier, Energy and Buildings, v. 37, n. 7, p. 762-776, 2005.

[9] Online available: http://www.energieinstitut.at/Retrofit/

[10] Ana Belén Rodríguez González, Juan José Vinagre Díaz, Antonio J. Caamaño, Mark Richard Wilby, "Towards a universal energy efficiency index for buildings", Elsevier, Energy and Buildings, V. 37, n. 4, p 980-987, 2011.

[11] C. Compagnon, "Solar and Daylight Availability in the Urban Fabric", Elsevier, Energy and Buildings, v. 36, n. 4, p. 321-328, 2004

[12] M. Arboit, A. Mesa, M. Basso, J. C. Fernández, C. De Rosa, "Morfología Urbana y Potencial Solar del Ambiente Construido en Ciudades Andinas de Trazado Hispánico: avances en la evaluación de entornos de baja densidad del área metropolitana de Mendoza”, Inenco, Avances en Energías Renovables y Medio Ambiente, v. 9, p. 55-60, 2005.
[13] N. A. Mesa, C. De Rosa, "La dinámica del crecimiento urbano disperso, en ciudades de zonas áridas andinas. Evaluación del impacto energético ambiental", Inenco, Avances en Energías Renovables y Medio Ambiente, v. 10, 2006.

[14] Robinson Darren, Computer modelling for sustainable urban design. Physical Principles, Methods and Applications, Editorial Earthscan. Londres, UK.G., 2011.

[15] Viegas, "Evaluación del Potencial Energético e Intervenciones de Mejoramiento del Entorno Edilicio en Áreas Urbanas de Media y Baja Consolidación: la ciudad de La Plata como caso de estudio", Tesis de Doctorado en Ciencias-área energías renovables, Universidad Nacional de Salta, Argentina, 2010.

[16] Duncan Timms. El mosaico Urbano: hacia una teoría de la diferenciación residencial. Editorial IEAL, Madrid, 1976.

[17] R. T. T. Forman. Mosaico Territorial para la Región Metropolitana de Barcelona, Editorial Gustavo Gili, España, 2004.

[18] Diputación De Barcelona. Sistema Municipal de Indicadores de Sostenibilidad. Edita: Diputación de Barcelona, España, 1996.

[19] Elio R. Di Bernardo, "Mosaico Interconectado de Naturaleza: una manera de restituir la dimensión natural en las áreas metropolitanas", Revista A\&P, n. 11, p. 4-7, 1996.

[20] G. Viegas, "Desarrollo metodológico a partir de mosaicos urbanos para evaluar la eficiencia energética y el aprovechamiento de la energía solar en el marco de la sustentabilidad urbana", Antac, Ambiente Construido, v. 11, n. 2, p. 139-155, 2011.

[21] Silvia D. Matteucci, Jorge Morello, Andrea F. Rodriguez, Nora E. Mendoza. El Alto Paraná Encajonado Argentino-Paraguayo: mosaicos de paisaje y conservación regional. Ediciones FADU, Argentina, 2004.

[22] Ministerio de Infraestructura, Subsecretaria de Obras Públicas, Departamento Fotogramétrico, provincia de Buenos Aires, Argentina, 1998.

[23] Online available: http://www.google.com/intl/es/earth/explor e/products/deskto $\mathrm{p} . \mathrm{html}$

[24] Martín Hurtado, Jorge Gimenez, Mirta Cabral. Análisis Ambiental del Partido de La Plata: Aportes al Ordenamiento Territorial. Instituto de Geomorfología y Suelos. Centro de Investigaciones de Suelos y Aguas de uso agropecuario CISAGUA-. Municipalidad de La Plata., $1^{\circ}$ Edición, Editor: Buenos Aires- Consejo Federal de Inversiones, Argentina, 2006.

[25] Alberto S.J. De Paula. La Ciudad de La Plata, sus tierras y su arquitectura. Ediciones del Banco de la Provincia de Buenos Aires, Argentina, 1987. 